\title{
Effect of Intercultivator on Performance Behavior of Cumbu Napier Hybrid Grass in North Eastern Zones of Tamilnadu, India
}

\author{
M. Suganthi*, Karu Pasupathi, and D. Balasubramanyam \\ Research Institute in Animal Sciences, Kattupakkam, \\ Tamil Nadu Veterinary and Animal Sciences University, India \\ *Corresponding author
}

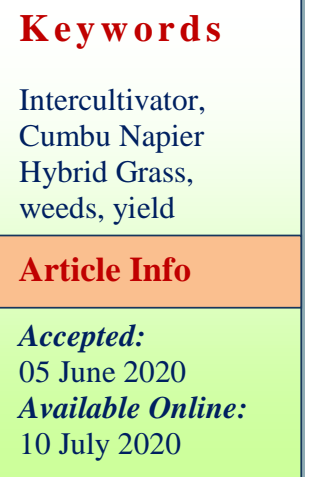

\section{A B S T R A C T}

The field experiment was conducted at Post Graduate Research Institute in Animal Sciences, Kattupakkam, Kancheepuram District, Tamil Nadu, India during Kharif (June-Sep) seasons of 2018-19 to make a study on the efficiency of intercultivator on weed management and crop growth in Cumbu Napier Hybrid grass variety CO4. The experiment was laid out with unpaired t test design. The two treatments of control (without intercultivator) and treatment (using intercultivator) were compared. Among the two treatments, using of intercultivator had positively influenced the growth and yield characters and number of cuttings and yield of Cumbu Napier Hybrid Grass. The maximum plant height, number of tillers hill ${ }^{-1}$, fodder yield were recorded under the treatment of using intercultivaor during Kharif. The fodder yield was lower in control which was not using the intercultivator for operation.

\section{Introduction}

Agriculture and animal husbandry are twin eyes of Indian Economy. There is a huge demand for green fodder. Country faces neatly $60 \%$ deficit in green fodder. Forage crops such as maize, sorghum, oat, barley, cowpea and berseem crops are palatable and nutritious but seasonal in nature (IGFRI, 2011). Due to this there is scarcity of fodder during the remaining period of year. The performance of the animals depends on the quantity and quality as well as availability of green fodder at various times during the year (Hatam et al., 2001). February and Higgins (2010) reported that grasses are advantageous than other plant species due to their adaptation and acclimatization to climate and soil.

Cumbu Napier Hybrid grass is an important perennial non-legume green fodder. Maintenance of $\mathrm{CN}$ hybrid is a tough task in the cement scenario of unavailability of labour. Cumbu-Napier Hybrid grass is widely distributed in tropical and sub-tropical regions 
of Asia, Africa, southern Europe and India. It is tall growing $(200-300 \mathrm{~cm})$, erect, stout, deep rooted, perennial grass. Pandey and Roy (2011) reported that among the improved fodder grass species, hybrid napier is multicut perennial grass with profuse tillering and very good tonnage throughout year.

It provides sustained fodder yields for four to five years thus save frequent expenses on repeated tillage and sowing operations. Hybrid Napier is resourceful forage grass due to its palatability, suitability for silage making and low oxalate content than any other grasses

Mechanical weeding keeps the soil surface loose by producing the soil mulch which results in better aeration and moisture conservation (Padole, 2007), beside reduce the weed problem. One of the main root cause for the failure of the Cumbu Napier Hybrid grass cultivation is timely unavailability of labour. One of the main root cause for the failure of Cumbu Napier Hybrid cultivation is failure in management of weeds.

Hence, weed management could not be achieved in time due to the shortage of labour. A intercultivater was used for the intercultivation and weeding operation (Vivek., 2013). Optimum Soil moisture content for performing intercultivation operation is important for effective tilting of soil (Mallikarjuna, 2017).

Due to its greater advantages of being smaller in size, less weight and easy to handle and cause less compaction of soil declaring it's movement on soil surface.

Intercultivation with cultivators increase the infiltration of rainwater and fertilizer use efficiency of the crop beside reduce the weed problem Hence the present study was carried out to know the efficiency of intercultivator.

\section{Materials and Methods}

The field experiment was conducted at Post Graduate Research Institute in Animal Sciences, Kattupakkam, Tamil Nadu, India during Kharif (June-Sep) seasons of 2016-17 to study the different crop establishment techniques on growth and yield of Cumbu Napier Hybrid grass variety CO-4.

The experiment was laid out with unpaired $t$ test design. Intercultivater with six tyne was used in treatment plot for weeding and tilting operation. It was operated at forty five days interval. For every time two consequent tilting of soil was carried out using intercultivator. In control plot labours are encaged to remove the weeds and further to tilt the soil.

In one year, totally six times intercultivator or weeding by using labour was done in between the crops. The area of cultivation was half an acre. Labour usage for treatment and control was compared in this system. The treatment of control (without intercultivator) and the treatment (using intercultivator) were compared. Among the two treatments, using of intercultivator, significantly influenced the growth and yield characters and yield of Cumbu Napier Hybrid Grass. The soil of the experimental field was clay loam. The experiments were replicated thrice.

The Co-4 variety of $\mathrm{CN}$ hybrid grass was used for comparison. Fresh planting materials were used for planting. Planting was done with the spacing of $75 \times 75 \mathrm{~cm}$ in treatmental plot and it is $50 \times 50 \mathrm{~cm}$ in control plot. In treatmental plot the spacing was increased to operate the intercultivator with six tyne. Crop production package of practices were followed as per the crop production guide. Observations on growth and yield characters were recorded during crop growth stages. Statistical analysis was done using unpaired $t$ test method. 


\section{Observation and analysis}

Plant growth characters such as plant height, number of tillers /hill, tiller weight (gm) and green fodder yield ( $t /$ ha/cutting) is influenced by use of intercultivator and control treatment were compared in this study. Use of intercultivator recorded significantly higher growth characters. The maximum plant height of $(183.8 \mathrm{~cm})$ was observed in treatment plot compared to control, Whereas number of tillers per hill was also higher in treatmental plots (14), higher tiller weight $(0.300 \mathrm{~g} /$ tiller $)$ and yield of the crop (105 t/ha/yr) was recorded under treatmental plot (use of intercultivator). Hence the green fodder yield was higher in treatmental plot (Table 1).

Maximum plant height in the treatmental plot might be due to timely removal of weeds and tilting of soil which enhances the better initial establishment. Further due to the operation of intercultivator between the $\mathrm{CN}$ hybrid grass improved the aeration of soil and thus increased the infiltration rate of water. Enhanced Initial establishment in the field and started growing at a faster might be attributed to higher plant height. During first cutting, the number of tillers produced was higher in treatmental plot compared to control. Further the weight of the tillers was higher in treatmental plot due to initial better establishment. Hence it increased the yield of the crop.
Maintaining optimum plant population and geometry led to availability of more resources to the plants that resulted in increased plant height, tiller weight and yield of fodder in stem cutting method of establishment. Loosening the soil, conservation of moisture by mulching and aeration of soil in the fodder crops increased the yield of the crop. (Sahay et al., 2016). This stem cutting method enhanced the plant height and reduced the number of tillers where as it improved the tiller weight and further yield of the green fodder in Cumbu Napier Hybrid grass.

The increase in the green fodder yield of treatmental plot was attributed to large root volume, strong tillers with higher tiller weight (Kadam et al., 2017). The similar results of best establishment technique increased the crop yield in paddy crop which was reported by Chandrapala et al., 2010.

\section{Results and Discussion}

Due to unavailability of labour the weeding operation was hampered in control plot. The yield of the fodder was varying significantly the cost incurred for intercultural operation was higher when human labourers were used. Increased yield of fodder in treatment plot may be expected in future by timely and efficient weed control and deep tilting of soil by using intercultivator.

Table.1 Effect of intercultivator on growth characters of CN Hybrid Grass

\begin{tabular}{|l|l|c|c|}
\hline S.No. & \multicolumn{1}{|c|}{ Parameters } & Treatment & Control \\
\hline 1. & Plant height & $183.82 \pm 0.087$ & $136.42 \pm 0.793$ \\
\hline 2. & Number of tillers/hill & $14.09 \pm 0.630$ & $16.08 \pm 0.410$ \\
\hline 3. & Tiller weight (gm) & $0.320 \pm 0.006$ & $0.134 \pm 0.001$ \\
\hline 4. & Green fodder yield (t/ha/cutting) & $105.9 \pm 1.15$ & $70.16 \pm 1.030$ \\
\hline
\end{tabular}


Table.2 Effect of intercultivator on comparing cost of production of CN Hybrid Grass

\begin{tabular}{|l|l|c|c|}
\hline \multicolumn{1}{|c|}{ S.No. } & \multicolumn{1}{|c|}{ Parameters } & Treatment & Control \\
\hline $\mathbf{1 .}$ & Number of labours used & 28 & 90 \\
\hline $\mathbf{2 .}$ & Cost involved & 9576 & 30780 \\
\hline $\mathbf{3 .}$ & Fuel charges (RS.) & 1654 & Nil \\
\hline $\mathbf{4 .}$ & $\begin{array}{l}\text { Comparing the cost with control } \\
\text { (percentage) }\end{array}$ & +68.88 & Nil \\
\hline
\end{tabular}

The yield of $\mathrm{CN}$ hybrid grass fodder was significantly higher in treatmental plot and the cost incurred for intercultivation is much lower and it is 68.8 percent lower in control plot compared to treatment plot.

\section{References}

Chandrapala, A.G., Yakadri,M., Kumar,R,M. and Raj, G.B.2010. Productivity and economics of rice -maize (zea mays) as influenced by methods of crop establishment, $\mathrm{Zn}$ and $\mathrm{S}$ application in rice. Indian J.Agron., 5:171-176.

February, E. C., and Higgins, S.I. 2010. The distribution of tree and grass roots in savannas in arelation to soil nitrogen and water. South African Journal of Botany 76: 517-52.

Hatam, M., Akmal, M., Habib, G. and Siddiqui, M. 2001. Status paper on establishment of fodder and forage discipline. NWFP Agriculture University Peshawar. Pp.105.

IGFRI, 2011. Vision-2030, Indain Grassland and Forage Research Institute, Jhansi (UP). p.2.

Mallikarjuna, V. R., 2017, Development and performance evaluation of rotary weeder matching to mini tractor. Published Ph.D. (Agril. Engg.) Thesis, Indira Gandhi Krishi Vishwavidhyalaya, Raipur.

Padole, Y. B., 2007, Performance evaluation of rotary weeder. Agric. Engg. Today., 4(2): 31.

Pandey, K.C., and Roy, A. K. 2011. Forage crops varieties, IGFRI, Jhansi. pp. 2527.

S.S. Kadam, Ashok Kumar and Mohd. Arif, 2017. Hybrid Napier for Round the Year Quality Fodder Supply to the Dairy Industry- A Review. Int.J.Curr.Microbiol.App.Sci (2017) 6(10): 4778-4783.

Sahay, Chandra Shekhar, Pathak, Prabha Kant and Singh, Sanjay Kumar 2016. Mechanization in Fodder Production. ICAR-Indian Grassland and Fodder Research Institute, Jhansi - 284003 (U.P.) India. Pp 1-42.

Vivek D. Raut, B.D.Deshmukh, Dinesh Dekate. 2013. Review paper on Various aspects of Weeders for Economical Cultivation. International Journal of Modern Engineering Research (IJMER), Vol. 3, Issue. 5, Sep - Oct. pp3296-3299 ISSN: 2249-6645

\section{How to cite this article:}

Suganthi. M., Karu Pasupathi, and Balasubramanyam. D. 2020. Effect of Intercultivator on Performance Behavior of Cumbu Napier Hybrid Grass in North Eastern Zones of Tamilnadu, India. Int.J.Curr.Microbiol.App.Sci. 9(07): 152-155.

doi: https://doi.org/10.20546/ijcmas.2020.907.018 